\title{
La metaevaluación de la Evaluación Docente Institucional en la USTA Una aplicación desde TRI.
}

\section{The meta-evaluation of the Institutional Teaching Evaluation on the USTA. An application from IRT.}

\author{
Lida Rubiela Fonseca Gómez ${ }^{1}$,, Esther Gutiérrez Mora² b, \\ Carlos Alfonso Orozco ${ }^{3}$, c, Lina María Fonseca Ortiz ${ }^{4}$, , Iliana Fernández Peña ${ }^{5}$ e, \\ Fabiola Inés Hernández Barriga ${ }^{6}{ }^{\mathrm{f}}$, \\ 1 Facultad de Estadística, Universidad Santo Tomás, Bogotá, Colombia \\ 2Socióloga, Investigador independiente, Bogotá, Colombia \\ 3,4,5,6 Unidad de Desarrollo Curricular y Formación Docente UDCFD, Universidad Santo Tomás, Bogotá, Colombia
}

\begin{abstract}
Resumen
La investigación sobre metaevaluación del desempeño docente institucional es un proyecto de largo plazo de la Universidad Santo Tomás, que aborda "la evaluación de la evaluación" como un proceso que articula las funciones sustantivas: docencia, investigación y proyección social dentro del quehacer docente en la Universidad. Un primer acercamiento se llevó a cabo en el año 2005 con el propósito de revisar y ajustar el modelo de evaluación, en el año 2012 se puso en discusión y análisis la validez y confiabilidad del instrumento utilizado, teniendo como referente los análisis cuantitativos y estadísticos para la comprensión de los diferentes actores que intervienen en la evaluación. Para lo cual, y desde la perspectiva de la metodología estadística, se parte de la teoría de respuesta al ítem (TRI) y el análisis factorial exploratorio.
\end{abstract}

Cabe señalar que la evaluación docente estudiantil (EDE), comúnmente es el método más usado en las universidades Latinoamericanas para evaluar la calidad de la enseñanza impartida por los docentes. Para este análisis se examinó el cuestionario de la EDE, usado por la Universidad Santo Tomás de Bogotá durante los periodos 2016-2017. Se realizó un estudio desde el enfoque de investigación mixto para caracterizar los resultados

\footnotetext{
aDocente tiempo completo Facultad de Estadística. E-mail: lidafonseca@usantotomas.edu.co

b Investigador externo. E-mail: esrural@gmail.com

c Docente tiempo completo. UDCFD. Universidad Santo Tomás. E-mail: carlosorozco@usantotomas.edu.co

d Docente tiempo completo. UDCFD. Universidad Santo Tomás. E-mail: linafonseca@usantotomas.edu.co

e Docente tiempo completo. UDCFD. Universidad Santo Tomás. E-mail: ilianafernandez@usantotomas.edu.co

f Directora. UDCFD Universidad Santo Tomás. E-mail: fabiolahernandez@usantotomas.edu.co
} 
obtenidos en diferentes niveles (divisiones, facultades y docentes) al interior de la Universidad. Así mismo, actualmente se exploran nuevas variables para el análisis de aquellos factores sociales y de contexto (institucional) que podrían incidir en los resultados que se obtienen. Muchos de ellos, no asociados a las competencias académicas de los profesores.

Palabras clave: Metaevaluación, Evaluación docente, TRI, Análisis factorial.

\begin{abstract}
The Research on the meta-evaluation of institutional teaching performance is a long-term project of the Universidad Santo Tomás, which approaches "the evaluation of evaluation" as a process that articulates the substantive functions: teaching, research and social projection within the teaching work at the University. The first approach was carried out in 2005 with the aim of reviewing and adjusting the evaluation model, in 2012 the validity and reliability of the instrument used were discussed and analyzed, taking as a reference the quantitative and statistical analyzes to understand the different actors involved in the evaluation. For which, and from the perspective of the statistical methodology, which is part of the item response theory (IRT) and exploratory factor analysis.

It should be noted that the student teacher evaluation (STE) is the most used method in Latin American universities to evaluate the quality of teaching provided by teachers. For this analysis the questionnaire (STE) used by the Universidad Santo Tomás between periods 2016-2017 was examined. A study was made from the mixed investigation approach to characterize the results obtained at different levels (divisions, faculties and teachers) inside the University. Likewise, currently new variables are being explored for the analysis of social and contextual factors that may affect the results obtained. Many of them, not associated to the academic competences of the professors.
\end{abstract}

Key words: Meta-evaluation, Teacher evaluation, IRT, factor analysis.

\title{
Referencias
}

Amigot, P. \& Martínez, L (2015), Procesos de subjetivación en el contexto neoliberal. El caso de la evaluación del profesorado y la investigación universitaria. RASE. Revista de Asociación de Sociología de la Educación, Volumen 8 № 2, mayo 2015.

Díaz, F. (2005), Enseñanza situada: Vínculo entre la escuela y la vida. Capítulo 5: La evaluación auténtica centrada en el desempeño: Una alternativa para evaluar el aprendizaje y la enseñanza. México: McGraw Hill.

Gutiérrez, E \& Zambrano A. (2017). La dimensión contextual en la comprensión de la evaluación docente -La Universidad Santo Tomás y su experiencia en el proceso de Metaevaluación del desempeño docente-. USTA.

Revista Portafolio. (2015), Colombia se rajó en dominio del inglés. Noviembre 10 de 2015. 
Santos, A. (2017), La gallina no es un águila defectuosa. Organización, liderazgo y evaluación en las instituciones educativas. Serie. Aseguramiento de la Calidad Educativa. Corporación Universitaria Minuto de Dios, Bogotá, 2017.

Sime, L, (1998). Metaevaluación: Ir más allá de la evaluación para volver sobre ella. Educación. Vol VII. N 14. Pontificia Universidad Católica del Perú. Departamento de Educación.

USTA, 2015. Lineamientos para el diseño y la actualización curricular. Ediciones USTA, Bogotá. USTA, 2010. Modelo Educativo Pedagógico. Bogotá. Ediciones USTA, Colombia.

USTA, 2010. Dimensión de la Política Docente. Bogotá, Colombia. Ediciones USTA, Colombia. USTA, 2015. Documento Marco Desarrollo Docente. Bogotá. Ediciones USTA, Colombia. 